\title{
Band gap tuning of amorphous Al oxides by Zr alloying
}

Canulescu, Stela; Jones, N. C.; Borca, C. N.; Piamonteze, C.; Rechendorff, Kristian; Gudla, Visweswara Chakravarthy; Bordo, Kirill; Nielsen, Lars Pleth; Hoffmann, Søren V.; Almtoft, K. P.

Total number of authors:

12

Published in:

Applied Physics Letters

Link to article, DOI:

$10.1063 / 1.4961941$

Publication date:

2016

Document Version

Publisher's PDF, also known as Version of record

Link back to DTU Orbit

Citation (APA):

Canulescu, S., Jones, N. C., Borca, C. N., Piamonteze, C., Rechendorff, K., Gudla, V. C., Bordo, K., Nielsen, L. P., Hoffmann, S. V., Almtoft, K. P., Ambat, R., \& Schou, J. (2016). Band gap tuning of amorphous Al oxides by $\mathrm{Zr}$ alloying. Applied Physics Letters, 109, [091902]. https://doi.org/10.1063/1.4961941

\section{General rights}

Copyright and moral rights for the publications made accessible in the public portal are retained by the authors and/or other copyright owners and it is a condition of accessing publications that users recognise and abide by the legal requirements associated with these rights.

- Users may download and print one copy of any publication from the public portal for the purpose of private study or research.

- You may not further distribute the material or use it for any profit-making activity or commercial gain

- You may freely distribute the URL identifying the publication in the public portal 


\section{A|P |Applied Physics \\ Letters}

\section{Band gap tuning of amorphous Al oxides by $\mathrm{Zr}$ alloying}

S. Canulescu, N. C. Jones, C. N. Borca, C. Piamonteze, K. Rechendorff, V. C. Gudla, K. Bordo, L. P. Nielsen, S.

V. Hoffmann, K. P. Almtoft, R. Ambat, and J. Schou

Citation: Applied Physics Letters 109, 091902 (2016); doi: 10.1063/1.4961941

View online: http://dx.doi.org/10.1063/1.4961941

View Table of Contents: http://scitation.aip.org/content/aip/journal/apl/109/9?ver=pdfcov

Published by the AIP Publishing

\section{Articles you may be interested in}

Anodic formation of highly ordered $\mathrm{TiO} 2$ nanotube arrays on conducting glass substrate: Effect of titanium film thickness

J. Vac. Sci. Technol. A 33, 061402 (2015); 10.1116/1.4926752

Band gap structure modification of amorphous anodic Al oxide film by Ti-alloying

Appl. Phys. Lett. 104, 121910 (2014); 10.1063/1.4866901

Band-gap tuning and nonlinear optical characterization of $\mathrm{Ag}$ : TiO 2 nanocomposites

J. Appl. Phys. 112, 074307 (2012); 10.1063/1.4757025

Density functional theory simulations of amorphous high-k oxides on a compound semiconductor alloy: a$\mathrm{Al} 2 \mathrm{O} 3 / \mathrm{InGaAs}(100)-(4 \times 2), \mathrm{a}-\mathrm{HfO} 2 / \mathrm{InGaAs}(100)-(4 \times 2)$, and a-ZrO2/InGaAs(100)-(4×2)

J. Chem. Phys. 135, 244705 (2011); 10.1063/1.3657439

Band structure modification of Al oxide by Ti-alloying and magnetoresistance behavior of magnetic tunnel junctions with Ti-alloyed Al oxide barrier

Appl. Phys. Lett. 86, 252501 (2005); 10.1063/1.1949726

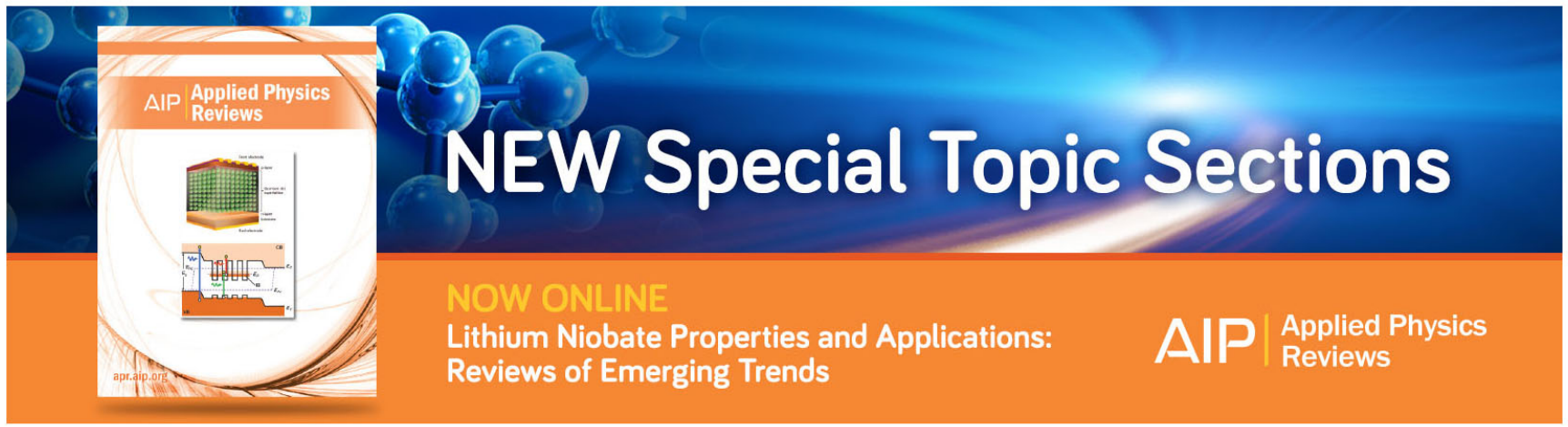




\title{
Band gap tuning of amorphous Al oxides by $\mathrm{Zr}$ alloying
}

\author{
S. Canulescu, ${ }^{1, a)}$ N. C. Jones, ${ }^{2}$ C. N. Borca,${ }^{3}$ C. Piamonteze,${ }^{3}$ K. Rechendorff, ${ }^{4}$ V. C. Gudla, ${ }^{5}$ \\ K. Bordo, ${ }^{5}$ L. P. Nielsen, ${ }^{4}$ S. V. Hoffmann, ${ }^{2}$ K. P. Almtoft, ${ }^{4}$ R. Ambat, ${ }^{5}$ and J. Schou ${ }^{1}$ \\ ${ }^{1}$ Department of Photonics Engineering, Technical University of Denmark, 4000 Roskilde, Denmark \\ ${ }^{2}$ ISA, Department of Physics and Astronomy, Aarhus University, 8000 Aarhus, Denmark \\ ${ }^{3}$ Swiss Light Source, Paul Scherrer Institut, 5232 Villigen PSI, Switzerland \\ ${ }^{4}$ Danish Technological Institute, Kongsvang Alle 29, 8000 Aarhus, Denmark \\ ${ }^{5}$ Department of Mechanical Engineering, Technical University of Denmark, 2800 Kgs-Lyngby, Denmark
}

(Received 16 July 2016; accepted 18 August 2016; published online 29 August 2016)

\begin{abstract}
The optical band gap and electronic structure of amorphous Al-Zr mixed oxides with $\mathrm{Zr}$ content ranging from 4.8 to $21.9 \%$ were determined using vacuum ultraviolet and X-ray absorption spectroscopy. The light scattering by the nano-porous structure of alumina at low wavelengths was estimated based on the Mie scattering theory. The dependence of the optical band gap of the Al-Zr mixed oxides on the $\mathrm{Zr}$ content deviates from linearity and decreases from $7.3 \mathrm{eV}$ for pure anodized $\mathrm{Al}_{2} \mathrm{O}_{3}$ to $6.45 \mathrm{eV}$ for $\mathrm{Al}-\mathrm{Zr}$ mixed oxides with a $\mathrm{Zr}$ content of $21.9 \%$. With increasing $\mathrm{Zr}$ content, the conduction band minimum changes non-linearly as well. Fitting of the energy band gap values resulted in a bowing parameter of $\sim 2 \mathrm{eV}$. The band gap bowing of the mixed oxides is assigned to the presence of the $\mathrm{Zr} d$-electron states localized below the conduction band minimum of anodized $\mathrm{Al}_{2} \mathrm{O}_{3}$. Published by AIP Publishing. [http://dx.doi.org/10.1063/1.4961941]
\end{abstract}

In recent years, many efforts have been dedicated to the development of high- $\kappa$ gate dielectric materials for advanced metal-oxide semiconductor (CMOS) devices. Aluminum oxide $\left(\mathrm{Al}_{2} \mathrm{O}_{3}\right)$ is one of the leading candidates to replace ultrathin $\mathrm{SiO}_{2}$ gate dielectrics for future CMOS technologies. ${ }^{1,2} \mathrm{Al}_{2} \mathrm{O}_{3}$ has a considerably larger dielectric constant than $\mathrm{SiO}_{2},{ }^{3}$ resulting in reduced gate leakage currents for layers of comparable thicknesses. ${ }^{1}$ Fabrication of ultra-thin pure or alloyed $\mathrm{Al}$ mixed oxides by anodic oxidation of $\mathrm{Al}$ or $\mathrm{Al}$ alloys, respectively, is one of the most cost-effective methods and it has been implemented at large industrial scale. Theoretical predictions have shown that alloying of $\mathrm{Al}_{2} \mathrm{O}_{3}$ with transition metals (TM) can result in a larger dielectric constant without significant reduction of the band gap of $\mathrm{Al}_{2} \mathrm{O}_{3}$. The possibility of tuning the structural and optical properties of $\mathrm{Al}_{2} \mathrm{O}_{3}$ by varying the alloying composition will broaden the range of materials available from pure oxides. Several studies were dedicated to understanding the electronic properties and changes in the band gap of amorphous anodic $\mathrm{Al}_{2} \mathrm{O}_{3}$ upon alloying. ${ }^{3-5}$ Theoretical studies based on density functional theory have shown that transition metal atoms, such as $\mathrm{Zr}$ atoms present in $\mathrm{Al}$ sites, introduce localized $d$-electron states below the conduction band (CB) of $\mathrm{Al}_{2} \mathrm{O}_{3} \cdot{ }^{6}$ Experimental determination of the band gap energy of $\mathrm{Zr}$-alloyed $\mathrm{Al}_{2} \mathrm{O}_{3}$ is not readily available because ultraviolet and visible measurements are limited to energies below $6 \mathrm{eV}$ due to the absorption of air. For a comprehensive electronic structure study, vacuum ultraviolet (VUV) spectroscopy is required to probe the valence-to-conduction band transitions in most high- $\kappa$ materials of large band gap. ${ }^{3}$

In this letter, the band gap of anodic $\mathrm{Al}-\mathrm{Zr}$ mixed oxide films was determined by vacuum ultraviolet spectroscopy (VUV), while the unoccupied conduction band states of the

\footnotetext{
${ }^{\text {a) }}$ Author to whom correspondence should be addressed. Electronic mail: stec@fotonik.dtu.dk
}

alloyed oxide films were investigated by X-ray absorption spectroscopy (XAS). The dependence of the energy gap of the anodic $\mathrm{Al}$ oxide films on the $\mathrm{Zr}$ alloying will be discussed.

Thin metallic films of Al-Zr alloys were deposited by DC magnetron sputtering on double-side polished sapphire substrates. Two Al targets (99.99\%) and two $\mathrm{Zr}$ targets (99.9\%, Hf being the primary impurity) were used for cosputtering the Al-Zr alloys. The film composition was adjusted by changing the relative power on the $\mathrm{Al}$ and $\mathrm{Zr}$ sputter targets, keeping the total power constant, while the sputtering time was appropriately set in order to deposit films of similar thickness. The anodization was performed in a dual-electrode cell, where an Al-Zr film on sapphire served as the anode and a Pt mesh served as the cathode. All films were anodized in $20 \%$ sulphuric acid at a constant voltage of $20 \mathrm{~V}$ at $18^{\circ} \mathrm{C}$. The anodization was stopped when the observed current density was stabilized at $0.1 \mathrm{~mA} / \mathrm{cm}^{2}$. The films were not sealed after anodizing, such that the anodized layer consists of a self-organized hexagonal porous structure with open pores. ${ }^{7}$ The $\mathrm{Zr}$ content in the as-sputtered films was determined by Rutherford Backscattering Spectrometry (RBS). The thickness of the resulting anodised films, measured by profilometry and cross section SEM, was varying between 180 to $380 \mathrm{~nm}$. Vacuum ultraviolet (VUV) spectroscopy measurements were carried out in the transmittance mode in the energy range from 4.13 to $9.18 \mathrm{eV}(300-135 \mathrm{~nm})$ at the AU-CD beamline of the ASTRID2 Synchrotron Light Source, Aarhus University, Denmark in a $\mathrm{N}_{2}$ purged chamber to avoid absorption of the UV light by air molecules. A baseline measurement of a clean sapphire substrate was acquired before and after each sample measurement. The resolution over the measured spectra range was constant with a value of $0.45 \mathrm{~nm}$. The XAS measurements at the oxygen Kedge were carried out at the X-Treme beamline ${ }^{8}$ at the Swiss Light Source, Paul Scherrer Institut, Switzerland. The 
measurements were performed in the total electron yield mode using circular in-plane polarization. The energy scans were recorded with the monochromator and insertion device moving continuously during scanning. ${ }^{9}$ This approach helps to reduce the surface charging, which unavoidably occurs on insulating samples. After background subtraction, all spectra were normalized to unity at $50 \mathrm{eV}$ above the oxygen K-edge.

The $\mathrm{Zr}$ content in the as-deposited films was estimated by Rutherford Backscattering Spectrometry (RBS) (see Table I). The X-ray Absorption Near-Edge Spectroscopy (XANES) spectra at the O K-edge are shown in Fig. 1(a). The O K-edge spectra reflect the unoccupied O $2 p$ (conduction band) states of the anodized Al-Zr films. A pre-peak feature located below the absorption threshold of the O K-edge (between 530 and $534 \mathrm{eV}$ ) is evident in all spectra. This low photon energy feature at the $\mathrm{O} \mathrm{K}$-edge is assigned to $\mathrm{O} 2 \mathrm{p}$ states hybridized with $\mathrm{Zr} 4 \mathrm{~d}$ states. ${ }^{10}$ The appearance of a pre-peak feature upon $\mathrm{Zr}$ alloying suggests that $\mathrm{Zr}$ replacing $\mathrm{Al}$ sites introduces localized $\mathrm{Zr} d$-electron states below the conduction band minimum (CBM) of aluminum oxide, ${ }^{6}$ which is in agreement with theoretical predictions by density functional theory. ${ }^{11}$ As it can be observed in Fig. 1(a), the intensity of the pre-peak increases monotonically with increasing $\mathrm{Zr}$ content from $4.8 \%$ to $15.8 \%$ due to a greater number of unoccupied $\mathrm{Zr} 4 \mathrm{~d}$ electron states available for mixing with the $\mathrm{O} 2 \mathrm{p}$ states. However, the intensity of the pre-peak corresponding to a $\mathrm{Zr}$ content of $21.9 \%$ no longer follows a linear increase and is comparable with that of $\mathrm{Zr}$ $15.8 \%$. The apparent "loss" in intensity may indicate a partial change in the local structure around oxygen atoms. The $\mathrm{X}$-ray diffraction pattern of the anodised Al-Zr films ( $\mathrm{Al}-\mathrm{Zr}$ mixed oxides) reveals that the all oxide films are amorphous (not shown). However, for the Al-film with a $\mathrm{Zr}$ content of $21.9 \%$, a peak associated with the monoclinic $\mathrm{ZrO}_{2}$ was observed. Therefore, the change in oxygen pre-peak edge intensity for a high $\mathrm{Zr}$ content can be explained by the fact that $\mathrm{Zr}$ is no longer fully replacing $\mathrm{Al}$ atoms and it can also be found in a mixed coordination state. The XAS spectra were used to determine the conduction band minimum (CBM) of alumina by extrapolating the leading edge of the XANES spectra to the baselines. The O K-edge shifts towards lower energy with increasing $\mathrm{Zr}$ content. The CBM shifts non-linearly with $\mathrm{Zr}$ content, as shown in Fig. 1(b).

The band gap of pure anodic amorphous $\mathrm{Al}_{2} \mathrm{O}_{3}$ and $\mathrm{Al}-\mathrm{Zr}$ mixed alloy oxides was determined from vacuum

TABLE I. Experimentally determined VUV optical band gap of anodized $\mathrm{Al}_{2} \mathrm{O}_{3}$ and $\mathrm{Al}-\mathrm{Zr}$ anodised alloys with the $\mathrm{Zr}$ content varying from $4.8 \%$ to 21.9\%. Reference data: optical band gap of single crystal $\gamma-\mathrm{Al}_{2} \mathrm{O}_{3}{ }^{3}$ and anodized $\mathrm{ZrO}_{2}{ }^{19}$

\begin{tabular}{|c|c|c|}
\hline \multicolumn{2}{|l|}{ Specimens } & Band gap energy $(\mathrm{eV})$ \\
\hline \multicolumn{2}{|l|}{ Single crystal $\gamma-\mathrm{Al}_{2} \mathrm{O}_{3}$} & 8.7 \\
\hline \multicolumn{2}{|c|}{ Amorphous anodized $\mathrm{Al}_{2} \mathrm{O}_{3}$} & 7.3 \\
\hline \multicolumn{2}{|c|}{ Anodized $\mathrm{ZrO}_{2}$} & 4.75 \\
\hline \multirow[t]{4}{*}{ Al-Zr mixed oxides } & $4.8 \% \mathrm{Zr}(\sim 340 \mathrm{~nm})^{\mathrm{a}}$ & 7.06 \\
\hline & $9.7 \% \mathrm{Zr}(\sim 330 \mathrm{~nm})$ & 6.8 \\
\hline & $15.8 \% \mathrm{Zr}(\sim 240 \mathrm{~nm})$ & 6.6 \\
\hline & $21.9 \% \mathrm{Zr}(\sim 340 \mathrm{~nm})$ & 6.45 \\
\hline
\end{tabular}

${ }^{\mathrm{a}}$ The thickness of the anodized films is given in parenthesis.
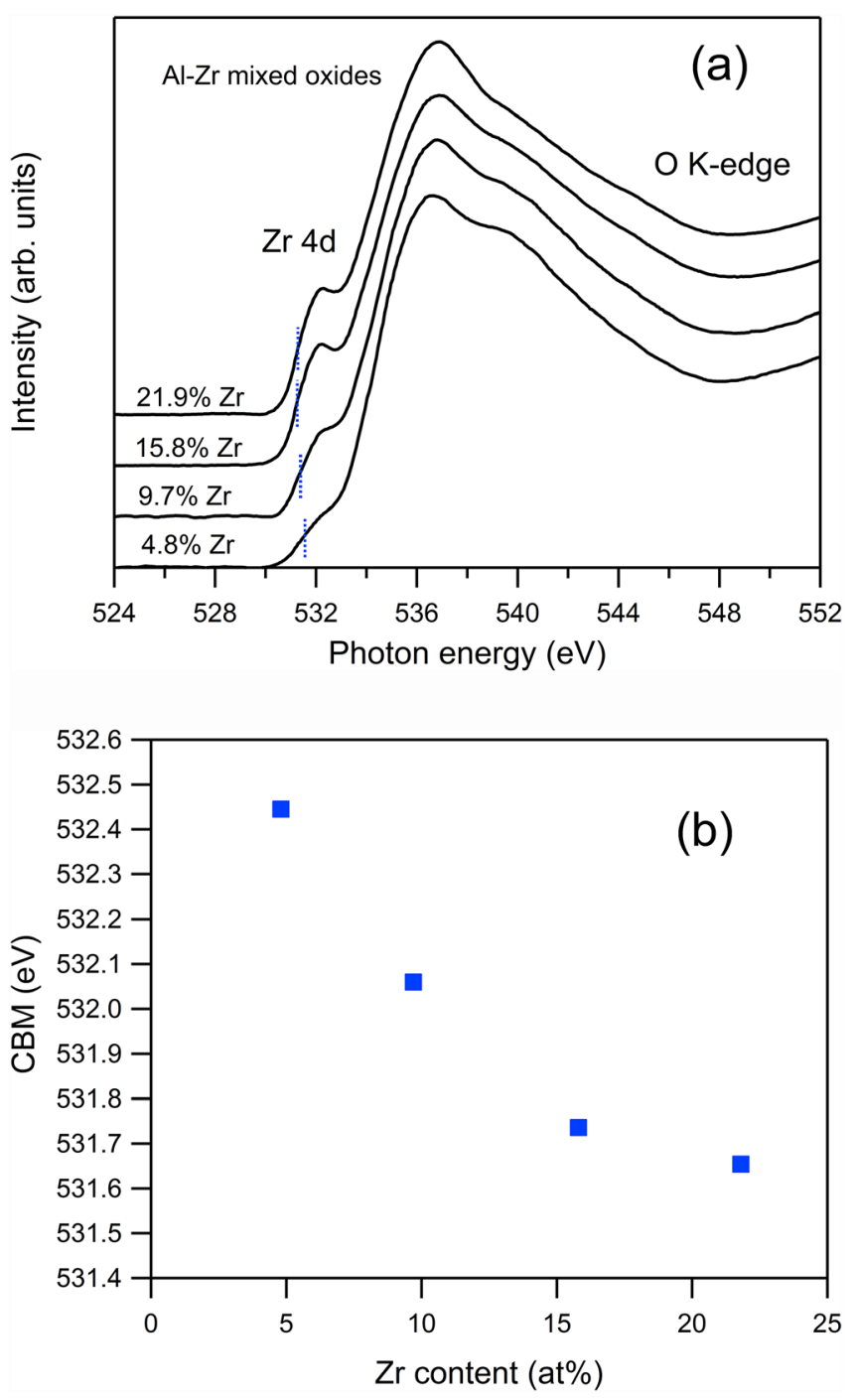

FIG. 1. (a) XAS spectra at the O K-edge of Al-Zr mixed oxides with $\mathrm{Zr}$ contents of 4.8, 9.7, 15.8 and 21.9\%; (b) Conduction band minimum (CBM) as a function of $\mathrm{Zr}$ content. The energy resolution was about $0.08 \mathrm{eV}$.

ultraviolet spectroscopy (VUV). The VUV transmittance spectra of the anodic oxide films on sapphire are shown in Fig. 2(a). The transparency of the oxide layers decreases markedly at short wavelengths, i.e. below $200 \mathrm{~nm}$. Amorphous $\mathrm{Al}_{2} \mathrm{O}_{3}$ shows a distinct absorption slope below $170 \mathrm{~nm}$. Upon $\mathrm{Zr}$ alloying, the absorption edge shifts to higher wavelengths (lower photon energy). As mentioned earlier, the anodized layer consists of a self-organized hexagonal porous structure with open pores ${ }^{7}$ with a typical diameter of $\sim 13 \mathrm{~nm}$ and porosity up to $14 \%{ }^{12}$ It is thus useful to discuss the nature of the sharp decrease in transparency of the mixed oxide layers with consideration of porosity (light scattering by nano-pores) and absorption contributions in alumina. Taking into account the size of the nanopores and the pore volume fraction of the oxide layers, we have estimated that the losses in transmittance due to scattering by nano-pores in alumina are negligible (see supplementary material). Since the size of the nano-pores and the volume fraction of the pores do not depend on the composition of the samples, but rather on the anodization voltage (which was kept constant for all samples), light scattering of the pores has an insignificant contribution to the transmission losses. 

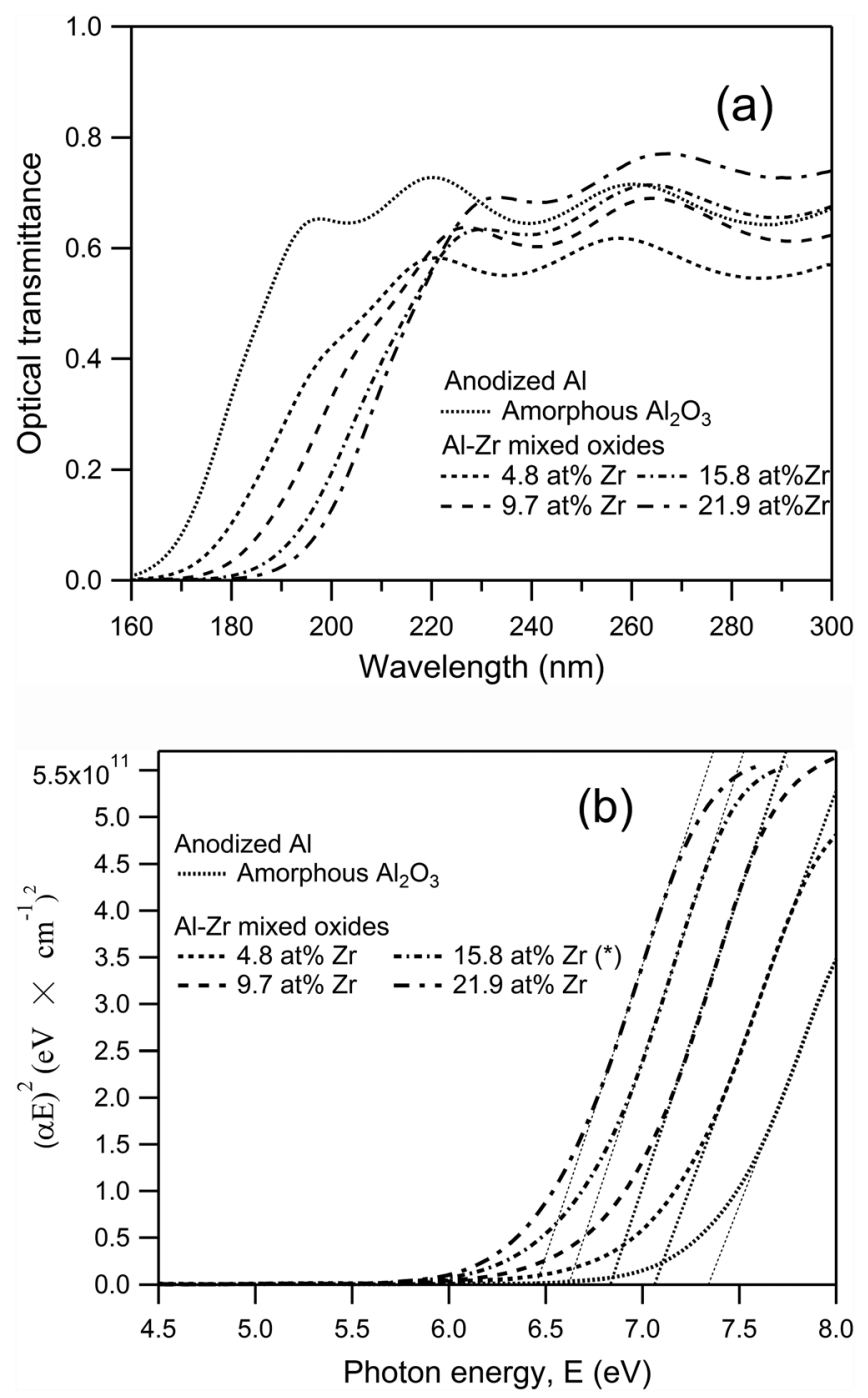

FIG. 2. (a) Vacuum ultraviolet (VUV) optical absorption coefficient of amorphous anodic $\mathrm{Al}_{2} \mathrm{O}_{3}$ and $\mathrm{Zr}$ - $\mathrm{Al}$ mixed oxides as a function of wavelength; (b) Plots of $(\alpha h \nu)$ versus $(\mathrm{h} \nu)$ for the $\mathrm{Zr}-\mathrm{Al}$ mixed oxide films with $\mathrm{Zr}$ contents of $4.8,9.7,15.8$ and $21.9 \%$. The plot $\left({ }^{*}\right)$ was divided by half for an easy visualization of the data.

Changes in the refractive index of the $\mathrm{Al}-\mathrm{Zr}$ mixed oxides by $5 \%$ with $\mathrm{Zr}$ content with respect to the pores leads to only about $1.5 \%$ variation in transmittance of the anodic layer. For the calculation of the band gap, we have therefore assumed that the incident light is either transmitted or absorbed, with scattering being negligible. ${ }^{13}$ The absorption coefficient for optical direct transitions is related to the incident photon energy by the relation ${ }^{14,15}$

$$
(\alpha \mathrm{E})^{2}=\left(\mathrm{E}-\mathrm{E}_{\mathrm{opt}}\right),
$$

where $\alpha, \mathrm{E}$, and $\mathrm{E}_{\mathrm{opt}}$ are the absorption coefficient, photon energy, and optical band gap, respectively. By replotting the data shown in Fig. 2(a) according to Eq. (1), optical band gap $\mathrm{E}_{\mathrm{opt}}$ was determined by extrapolating the linear dependence of $(\alpha \mathrm{E})^{2}$ to zero. This plot is shown in Fig. 2(b) for pure $\mathrm{Al}_{2} \mathrm{O}_{3}$ and $\mathrm{Zr}$-alloyed $\mathrm{Al}_{2} \mathrm{O}_{3}$ with $\mathrm{Zr}$ content varying from $4.8 \%$ to $21.8 \%$. The determined optical band gap values are also summarized in Table I. Amorphous anodized $\mathrm{Al}_{2} \mathrm{O}_{3}$ has a direct band gap of $7.3 \mathrm{eV}$, which is about $1.4 \mathrm{eV}$ lower than the crystalline counterpart, i.e., $8.7 \mathrm{eV}$ for single crystal $\gamma-\mathrm{Al}_{2} \mathrm{O}_{3}{ }^{3}$ (see Table I). A lower optical band gap of amorphous oxide compared to its crystalline counterpart can be associated with the different band structure resulting from a broad distribution of bond angles and distances. ${ }^{4,5}$ In fact, it was shown that the band gap of $\mathrm{Al}_{2} \mathrm{O}_{3}$ can be increased by $\sim 1 \mathrm{eV}$ from an amorphous to a crystalline structure by annealing induced crystallization. ${ }^{16}$ Filatova et al. ${ }^{17}$ have suggested that the variation in the energy gap between amorphous and crystalline $\mathrm{Al}_{2} \mathrm{O}_{3}\left(\alpha-\mathrm{Al}_{2} \mathrm{O}_{3}\right)$ is due to a shift of the bottom of the conduction band. The optical band gap of anodic amorphous $\mathrm{Al}_{2} \mathrm{O}_{3}$ decreases upon $\mathrm{Zr}$ alloying from $7.06 \mathrm{eV}$, corresponding to a $\mathrm{Zr}$ content of $4.8 \%$, to $6.45 \mathrm{eV}$ where the $\mathrm{Zr}$ content is $21.9 \%$. A reduction of the band gap of anodic $\mathrm{Al}_{2} \mathrm{O}_{3}$ was also reported for other transition metalalloyed $\mathrm{Al}_{2} \mathrm{O}_{3}$, such as $\mathrm{Nb}^{4}$ and $\mathrm{Ti}^{3}$. On the other hand, alloying of $\mathrm{Al}_{2} \mathrm{O}_{3}$ with $\mathrm{Sc}$ and $\mathrm{Y}$ was shown to induce little change in the band gap of $\mathrm{Al}_{2} \mathrm{O}_{3}{ }^{6}{ }^{6}$

The electronic structure of $\mathrm{Al}_{2} \mathrm{O}_{3}$ is well understood. ${ }^{14}$ The top of the valence band (VB) arises from $\mathrm{O} 2 \mathrm{p}$ orbitals, while the bottom of the conduction band (CB) arises from delocalized $\mathrm{Al}$ 3s empty states and $\mathrm{Al} 3 \mathrm{p}$ states higher up in the $\mathrm{CB}$. The energy gap in $\mathrm{Al}_{2} \mathrm{O}_{3}$ is due to electronic transitions from $\mathrm{O} 2 \mathrm{p}$ to $\mathrm{Al} 3 \mathrm{~s}$ orbitals. ${ }^{14}$ Band-gap state analysis of the Al-Zr mixed oxides suggests the formation of an impurity band below the $\mathrm{CBM}$ of $\mathrm{Al}$ oxide upon $\mathrm{Zr}$ alloying. Hence, band to band transitions in Al-Zr mixed oxides can be associated with transitions from the populated $\mathrm{O} 2 \mathrm{p}$-states at the top of the $\mathrm{VB}$ to the empty $\mathrm{Zr} 4 d$-electron states located below the CBM.

In order to describe the compositional dependence of the band gap of the Al-Zr mixed oxides, we have used the standard bowing equation, which can be described as ${ }^{18}$

$$
\begin{aligned}
E_{g}(\mathrm{Al}-\mathrm{Zr} \text { mixed oxides })= & (1-x) E_{g}\left(\mathrm{Al}_{2} \mathrm{O}_{3}\right) \\
& +x E_{g}\left(\mathrm{ZrO}_{2}\right)-b x(1-x),
\end{aligned}
$$

where $E_{g}\left(\mathrm{Al}_{2} \mathrm{O}_{3}\right), E_{g}\left(\mathrm{ZrO}_{2}\right)$, and $E_{g}(\mathrm{Al}-\mathrm{Zr}$ mixed oxides $)$ are the band gaps of $\mathrm{Al}_{2} \mathrm{O}_{3}, \mathrm{ZrO}_{2}$, and $\mathrm{Al}-\mathrm{Zr}$ mixed oxides, respectively. The parameter $b$ is known as the bowing parameter and represents the deviation of the band gap from linearity. The variation of the band gap as a function of alloying content is plotted in Fig. 3, while the dashed line describes the fitting according to Eq. (2). The fitting was done using the direct band gap of anodic amorphous $\mathrm{Al}_{2} \mathrm{O}_{3}$ of $7.3 \mathrm{eV}$ and of anodic amorphous $\mathrm{ZrO}_{2}$ of $4.8 \mathrm{eV} .{ }^{19}$ Fitting of the experimental data with the parabolic function results in a bowing parameter value $b$ of $2 \pm 0.2 \mathrm{eV}$. The determined bowing parameter is lower than the one reported for anodic Al-Nb mixed oxides, i.e., $4.3 \mathrm{eV}$. $^{4}$ Typically, a small value of the bowing parameter, and thus a small deviation from the linearity of the band gap of alloys, can indicate a good miscibility of the alloys, such as $b=0.1$, as estimated from polycrystalline CZGTS (Se) alloys. ${ }^{20}$ A larger value of the bowing parameter, such as the one determined here and also reported for $\mathrm{Al}-\mathrm{Nb}$ mixed oxides, indicates that the randomness in the alloys strongly influences the energy gap of the alloys.

The compositional dependence of a band gap can originate from three distinct contributions: (i) change in the band structure due to change of the lattice constant upon alloying, (ii) modified atom positions with the internal structural 


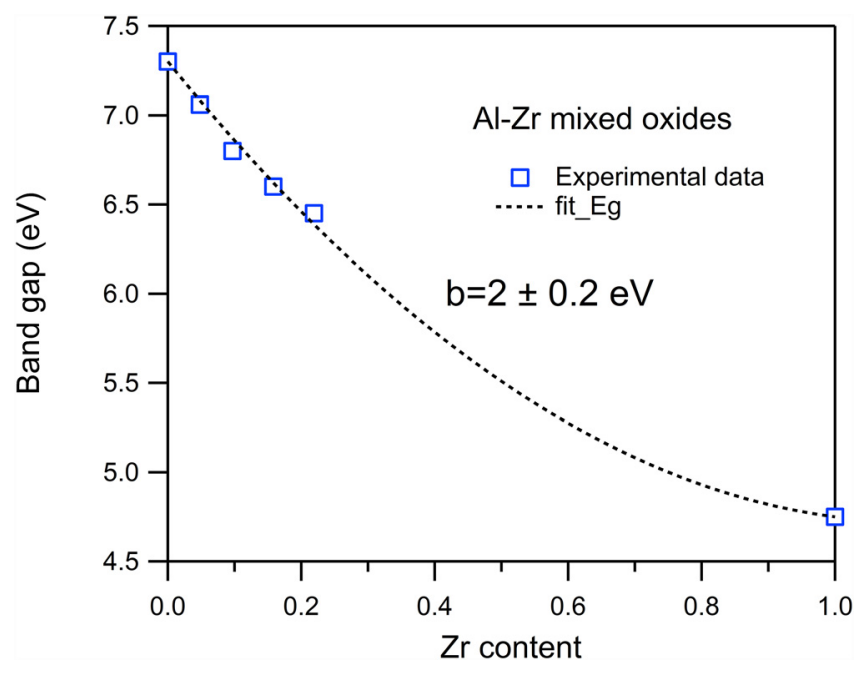

FIG. 3. Optical band gap energy $\left(E_{\text {opt }}\right)$ estimated from the VUV absorption spectra as a function of $\mathrm{Zr}$ content, $x$. The dotted line represents band bowing fitting according to Eq. (2) resulting in a bowing parameter of (b) of $2 \pm 0.2 \mathrm{eV}$.

relaxation of the bond lengths of the alloys, and (iii) charge exchange owing to different electronegativity of alloyed systems resulting in localized energy levels below the CBM. ${ }^{21}$ The bowing behaviour observed in the Al-Zr mixed alloys can be attributed to charge exchange resulting in localized delectron states below the band gap minimum of alumina, since all anodic films are amorphous. This is also supported by the XAS findings, which reveal the presence of $\mathrm{Zr}$ delectron states below the CBM of alumina alloys. Obviously, $\mathrm{Zr}$-alloying in the alumina leads to a redistribution of the valence band/conduction band levels while the non-linear shift of the CBM with increasing $\mathrm{Zr}$ content supports the existence of a bowing behaviour. At a low $\mathrm{Zr}$ content $(4.8 \%)$ the $\mathrm{Zr} d$-electron states are localized below the CBM of alumina. The high degree of localization was theoretically predicted for Al-Zr mixed oxides with $\mathrm{Zr}$ content in alumina of 6.5 at. \% ${ }^{11}$ Thus, the impurity band in alumina persists at a $\mathrm{Zr}$ content of $4.8 \%$. However, more strongly localized $\mathrm{Zr} 4 \mathrm{~d}$ states exist in $15.8 \% \mathrm{Zr}$-alloyed $\mathrm{Al}_{2} \mathrm{O}_{3}$ compared to $21.8 \%$ $\mathrm{Zr}$-alloyed $\mathrm{Al}_{2} \mathrm{O}_{3}$. This indicates that for a large $\mathrm{Zr}$ content $(21.8 \%)$, the $\mathrm{Zr} d$-electron states merge with the extended states in the conduction band. It is thus expected that the conduction band minimum moves continuously with increasing concentration according to Eq. (2).

In summary, we have experimentally determined the optical band gap of Al-Zr mixed oxides by vacuum ultraviolet spectroscopy (VUV). Optical losses due to light scattering by the nano-porous structure of alumina at UV wavelengths were estimated to be negligible. The $\mathrm{Zr}-\mathrm{Al}$ mixed oxides have a band gap that varies, decreasing from $7.06 \mathrm{eV}$ to $6.45 \mathrm{eV}$ with increasing $\mathrm{Zr}$ content from $4.8 \%$ to $21.9 \%$. The optical band gap decreases monotonically with increasing $\mathrm{Zr}$ content, showing a band bowing behaviour with a bowing parameter of $2.2 \mathrm{eV}$. The band bowing in $\mathrm{Zr}-\mathrm{Al}$ mixed oxides arises from the non-linear shift of the conduction band minimum with the $\mathrm{Al}$ content.

See supplementary material for the calculation of the transmission losses in alumina due to light scattering by nano-pores.

The financial support from the Danish National Advanced Technology Foundation is greatly acknowledged.

${ }^{1}$ Y. C. Chang, W. H. Chang, H. C. Chiu, L. T. Tung, C. H. Lee, K. H. Shiu, M. Hong, J. Kwo, J. M. Hong, and C. C. Tsai, Appl. Phys. Lett. 93, 053504 (2008).

${ }^{2}$ G. D. Wilk, R. M. Wallace, and J. M. Anthony, J. Appl. Phys. 89, 5243 (2001).

${ }^{3}$ S. Canulescu, K. Rechendorff, C. N. Borca, N. C. Jones, K. Bordo, J. Schou, L. Pleth Nielsen, S. V. Hoffmann, and R. Ambat, Appl. Phys. Lett. 104, 121910 (2014).

${ }^{4}$ M. Santamaria, F. Di Franco, F. Di Quarto, P. Skeldon, and G. E. Thompson, J. Phys. Chem. C 117, 4201 (2013).

${ }^{5}$ M. Santamaria, F. Di Quarto, and H. Habazaki, Corros. Sci. 50, 2012 (2008).

${ }^{6}$ R. J. Jung, J. C. Lee, Y. W. So, T. W. Noh, S. J. Oh, J. C. Lee, and H. J. Shin, Appl. Phys. Lett. 83, 5226 (2003).

${ }^{7}$ V. C. Gudla, S. Canulescu, R. Shabadi, K. Rechendorff, K. Dirscherl, and R. Ambat, Appl. Surf. Sci. 317, 1113 (2014).

${ }^{8}$ C. Piamonteze, U. Flechsig, S. Rusponi, J. Dreiser, J. Heidler, M. Schmidt, R. Wetter, M. Calvi, T. Schmidt, H. Pruchova, J. Krempasky, C. Quitmann, H. Brune, and F. Nolting, J. Synchrotron. Radiat. 19, 661 (2012).

${ }^{9}$ J. Krempasky, U. Flechsig, T. Korhonen, D. Zimoch, Ch. Quitmann, and F. Nolting, AIP Conf. Proc. 1234, 705 (2010).

${ }^{10}$ F. M. F. Degroot, M. Grioni, J. C. Fuggle, J. Ghijsen, G. A. Sawatzky, and H. Petersen, Phys. Rev. B 40, 5715 (1989).

${ }^{11}$ M. Haverty, A. Kawamoto, K. Cho, and R. Dutton, Appl. Phys. Lett. 80, 2669 (2002)

${ }^{12}$ T. P. Woodman, Thin Solid Films 9, 195 (1972).

${ }^{13}$ G. K. Mor, O. K. Varghese, M. Paulose, and C. A. Grimes, Adv. Funct. Mater. 15, 1291 (2005).

${ }^{14}$ R. H. French, J. Am. Ceram. Soc. 73, 477 (1990).

${ }^{15}$ E. A. Davis and N. F. Mott, Philos. Mag. 22, 903 (1970).

${ }^{16}$ D. Tahir, H. L. Kwon, H. C. Shin, S. K. Oh, H. J. Kang, S. Heo, J. G. Chung, J. C. Lee, and S. Tougaard, J. Phys. D: Appl. Phys. 43, 255301 (2010).

${ }^{17}$ E. O. Filatova and A. S. Konashuk, J. Phys. Chem. C 119, 20755 (2015).

${ }^{18}$ X. Wang, K. Saito, T. Tanaka, M. Nishio, T. Nagaoka, M. Arita, and Q. Guo, Appl. Phys. Lett. 107, 022111 (2015).

${ }^{19}$ F. Trivinho-Strixino, F. E. G. Guimaraes, and E. C. Pereira, Chem. Phys. Lett. 461, 82 (2008).

${ }^{20}$ D. B. Khadka and J. H. Kim, J. Phys. Chem. C 119, 1706 (2015).

${ }^{21}$ S.-H. Wei and A. Zunger, Phys. Rev. Lett. 76, 664 (1996). 